\title{
FINANCIAL LITERACY AMONG CSU STUDENTS
}

\author{
Melinda Verano Abichuela
}

Associate Professor, College of Business and Accountancy, Catanduanes State University, Virac, Island, Catanduanes, Philippines.

\section{ABSTRACT}

Financial Literacy is the upshot of responsiveness, profound knowledge, skill, attitude and behavior associated with money, credit and banking necessary to make exceptional financial decisions. Promoting financial literacy is indispensable to realize immense financial inclusion and enhance Economic Development. College students are the ideal recipients of financial literacy programs for the reason that many college students need this as a significant factor in their savings, credit and investment decisions and they will enter the workforce upon graduation. They will be accountable for managing their salary, investment options and retirement accounts. They will embark on making decisions that can impact their financial well-being will allow them to make more responsible financial decisions later on and mature into financially literate and independent adults. While the prior researches has afforded evidence of people's personal finance knowledge and improved our understanding of the issue, many studies cover selected areas in personal finances, neglecting others. These limitations are compounded by the fact that many prior studies only report the levels of financial literacy without analyzing the significance that influence people's knowledge. None of the previous studies have examined the financial literacy among college students, especially in Catanduanes. This crucial aspect is the gap which was bridged by the present study.

This study determined the financial literacy programs needed by CSU students. I collected primary data from the information provided by One Hundred Ninety Nine third year students respondents who participated in the in-depth face-to-face interview, a stratified random sampling was rationally chosen for the research.

The financial literacy programs needed by CSU students are (a) personal finance, (b) budgeting, (c) bookkeeping, (d) savings, (e) investment, (f) credit management, and (g) pension planning. From the interview of the respondents, on the financial literacy programs. It was found out that majority of those knowledgeable in personal finance are students in BS Accountancy, followed by BS Accounting Technology, BSBA-fm, BSBA-marketing, BSBA-human resource development management, BS entrepreneurship, and BS office administration. Students from other colleges of the csu 
are not skilled nor knowledgeable in financial matters. The outcome that business majors are more knowledgeable in financial literacy programs is consistent with findings of previous researches. The research paper advocates Higher educational institutions inclusion in their curriculum of non-business courses, subjects on financial literacy and an action plan to enhance and develop the students sound financial decisions. A research on financial literacy in other universities must be conducted to replicate this study and may use other variables.

Key words: financial literacy, csu, university, students, catanduanes.

Cite this Article: Melinda Verano Abichuela, Financial Literacy Among CSU

Students, International Journal of Management, 11(12), 2020, pp 2039-2044.

http://iaeme.com/Home/issue/IJM?Volume=11\&Issue=12

\section{INTRODUCTION}

Financial Literacy is the upshot of responsiveness, profound knowledge, skill, attitude and behavior associated with money, credit and banking necessary to make exceptional financial decisions.

Lusardi and Mitchell (2007b, p.36) used the definition of OECD (2005). Accordingly, financial education is defined as "the process by which financial consumers/investors improve their understanding of financial products and concepts, and through information, instruction, and/ or objective advice, develop the skills and confidence to become more aware of financial risks and opportunities to make informed choices, to know where to go for help, and to take other effective actions to improve their financial well-being". Servon and Kaestner (2008, p.273) defines financial literacy as "a person's ability to understand and make use of financial concepts".

The Catanduanes State University is an institution of Higher learning, which caters to the needs of the students. The total population of the University for the First semester, 2016-2017 all third year students is 1,863 and for the purpose of this study, I have chosen $10 \%$ of the population which is 199 as the ideal sample.

It was ascertained by the World Bank Country Director Motoo Konishi that in a society, people with magnanimous knowledge about financial literacy matters, this can succour them access financial services. Promoting financial literacy is therefore indispensable to realize immense financial inclusion and enhance Economic Development.

Global financial literacy is instituted to be low as measured by various studies including the OECD survey. According to the Consultative Group to Assist the Poor (CGAP) and the World Bank, projected that around 2.7 billion adults worldwide do not have ingress to credit, insurance, or savings with a bank or other formal institution, Ehrbeck, Pickens, and Tarazi (2012). An investigation by Bernheim, Garrett, and Maki (2001) disclosed that consumers who graduated from countries with mandated financial literacy were having higher savings rates and higher net worth.

The Philippine government has eminently identified financial literacy as an important strategy, among others, for poverty alleviation and inclusive growth (Philippine Development Plan 2011-2016).

College students are the ideal recipients of financial literacy programs for the reason that many college students need this as a significant factor in the credit card decisions, Robb(2011) and they will enter the workforce upon graduation. They will be accountable for managing their salary, investment options and retirement accounts. They will embark on making decisions that 
can impact their financial well-being will allow them to make more responsible financial decisions later on, Remund (2010) and mature into financially literate and independent adults.

The study of Remund(2010) and Robb(2011) on Financial literacy is cogently consistent with R.A. 10679 which mandates the Commission On Higher Education (CHED) to establish promotion of programs on Entrepreneurship and financial literacy in the Philippines.

It has been disclosed that in the Philippines, only $25 \%$ of Filipinos are financially literate, Standard \& Poor Ratings Services, (2016).

It was also accentuated by Nurul Wajhi Ahmad et al., (2016); (Altintas, 2011) that meagre financial literacy among college students is linked with dismal financial behaviors, including low savings, poor record keeping and more credit card debt. Enormous number of students enrol in college with no budgeting and savings competence and are accountable to spend and use credit imprudently. This penchant of superfluous debt, low income, and low levels of financial literacy harmfully defeats college student financial refuge and is an impediment for economic development. It was manifested by $\operatorname{Kaur}(2015)$ that it is only through financial literacy that people elevate their ingenuity of the financial products and services and substantiate a lifetime of financial well-being.

In Catanduanes there is a massive growth of financially multifaceted products to the retail marketplace, including student loans, mortgages, credit cards, insurance and pension accounts, many of these have proven to be challenging for financial investors. Innumerable consumers are victims of bogus transactions. Therefore, this paper strongly recommends, amongst others, the involvement of government agencies as well as key higher educational institutions and the private sector in the design and implementation of curriculum and financial literacy programmes and provide a starting point for those institutions seeking to start a new financial literacy course or program on their respective colleges or university.

\section{METHODOLOGY}

Present study was carried out at the Catanduanes State University in Island Catanduanes. Catanduanes State University is rapidly emerging as one of the Best Universities in the Philippines. In this study in-depth interviews in which a semi-structured interview schedule was used as the main data gathering tool. It is a qualitative research because its foundation was to clarify and gain knowhow and understanding of occurrence through collection of narrative data which in this study happened during the face-to-face in-depth interview with the respondents.

Primary data were gathered from the $3^{\text {rd }}$ year students enrolled for the First Semester, S.Y. 2016-2017, a stratified random sampling was employed in this study which include 199 csu students from different colleges of the university as the sample.

\section{FINDINGS AND DISCUSSIONS}

\subsection{Characteristics of the respondents}

Majority of the respondents are female and ages 18 to 22 years old.

\subsection{Financial literacy programs needed by the respondents.}

From the interview of the respondents, on the financial literacy programs, it was found out that majority of those knowledgeable in personal finance are students in BS Accountancy, followed by BS Accounting Technology, BSBA-fm, BSBA-marketing, BSBA-human resource development management, BS entrepreneurship, and BS office administration. Students from other colleges of the csu are not skilled nor knowledgeable in financial matters. The outcome that business majors are more knowledgeable in financial literacy programs is consistent with findings of previous researches. The result is not shocking because curriculum requirements of 
students at the college of business and accountancy give them more opportunity to take finance and related business courses.

\section{CONCLUSION AND RECOMMENDATIONS}

From the findings, CSU students as respondents are dominated by female and majority ages 18 to 22 years old.

The financial literacy programs needed by CSU students are in terms of (a) personal finance, (b) budgeting, (c) bookkeeping, (d) savings, (e) investment, (f) credit management, and (g) pension planning.

From the interview of the respondents, on the financial literacy programs from a to $g$, it was found out that majority of those knowledgeable in personal finance are students in BS Accountancy, followed by BS Accounting Technology, BSBA-fm, BSBA-marketing, BSBAhuman resource development management, BS entrepreneurship, and BS office administration. Students from other colleges of the csu are not skilled nor knowledgeable in financial matters. The outcome that business majors are more knowledgeable in financial literacy programs is consistent with findings of previous researches. The result is not shocking because curriculum requirements of students at the college of business and accountancy give them more opportunity to take finance and related business courses.

\subsection{Recommendations}

Based on the findings and conclusions drawn, the following recommendations are offered:

- The respondents who are Non-Business majors are deficient in the indispensable knowledge and skills in financial literacy, which include the following: (a) personal finance, (b) budgeting, (c) bookkeeping, (d) savings, (e) investment, (f) credit management, and $(\mathrm{g})$ pension planning. Higher educational institutions must include in the curriculum of non-business courses subjects on financial literacy.

- A research on financial literacy in other universities must be conducted to to replicate this study and may use other variables.

\section{REFERENCE}

[1] Agarwal, Sumit, John C. Driscoll, Xavier Gabaix, and David Laibson (2009) The Age of Reason: Financial Decisions Over the Life Cycle and Implications for Regulation, Brookings Papers on Economic Activity, Fall 2009, pp. 51-117.

[2] Agnew, Julie R., and Lisa R. Szykman (2005), Asset Allocation and information Overload: The Influence of Information Display, Asset Choice and Investor Experience, The Journal of Behavioral Finance, 6(2), pp. 57-70.

[3] Alessie, Rob, Maarten van Rooij, and Annamaria Lusardi (2011a), Financial Literacy and Retirement Preparation in the Netherlands, Journal of Pension Economics and Finance, 10(4), pp. 527-545.

[4] Almenberg, Johan, and Anna Dreber (2011), Gender, Financial Literacy and Stock Market Participation, Stockholm School of Economics Economic Research Institute Working Paper, no. 737.

[5] Almenberg, Johan, and Jenny Säve-Söderbergh (2011), Financial Literacy and Retirement Planning in Sweden, Journal of Pension Economics and Finance, 10(4), pp. 585-598. 


\section{Melinda Verano Abichuela}

[6] Arrondel, Luc, Majdi Debbich, and Frédérique Savignac (2013), Financial Literacy and Financial Planning in France, Numeracy, 6(2), Article 8.

[7] Beckmann, Elisabeth (2013), Financial Literacy and Household Savings in Romania, Numeracy, 6(2), Article 9.

[8] Boggio, Cecilia, Elsa Fornero, Henriette Prast, and Jose Sanders (2014), Seven Ways to Knit Your Portfolio: Is Investor Communication Neutral?, CeRP Working Paper, no. 140/14.

[9] Boisclair, David, Annamaria Lusardi and Pierre-Carl Michaud (2014), Financial Literacy and Retirement Planning in Canada, NBER Working Paper, no. 20297, forthcoming Journal of Pension Economics and Finance.

[10] Bucher-Koenen, Tabea, and Johannes Koenen (2015), Do Seemingly Smarter Consumers Get Better Advice?, Max-Planck-Institute for Social Law and Social Policy, MEA Discussion Paper $1-2015$

[11] Bucher-Koenen, Tabea (2011), Financial Literacy, Riester Pensions and Other Private Old Age Provision in Germany, Max-Planck-Institute for Social Law and Social Policy, MEA Discussion Paper.

[12] Bucher-Koenen, Tabea, and Michael Ziegelmeyer (2014), Once Burned, Twice Shy? Financial Literacy and Wealth Losses during the Financial Crisis, Review of Finance, 18 (6).

[13] Crossan, Diana, David Feslier, and Roger Hurnard (2011), Financial Literacy and Retirement Planning in New Zealand, Journal of Pension Economics and Finance, 10(4).

[14] Deuflhard, Florian, Dimitris Georgarakos, and Roman Inderst (2015), "Financial Literacy and Savings Account Returns,” ECB Working Paper, no. 1852.

[15] Hastings, Justine, Brigitte Madrian, and William Skimmyhorn (2013), Financial Literacy, Financial Education, and Economic Outcomes, Annual Review of Economics, 5.

[16] Kalmi, Panu and Olli-Pekka Ruuskanen (2015),Financial Literacy and Retirement Retirement Planning in Finland. Working paper, University of Vaasa.

[17] Klapper, Leora, Annamaria Lusardi and Peter van Oudheusden (2015), Financial Literacy around the World: Insights from the Standard and Poor's Ratings Services Global Financial Literacy Survey, Working Paper, Global Financial Literacy Excellence Center.

[18] Luehrmann, Melanie, Marta Serra-Garcia, and Joachim Winter (2015), Teaching Teenagers in Finance: Does It Work?, Journal of Banking and Finance, 54.

[19] Lusardi, Annamaria, Punam Keller, and Adam Keller (2008), New Ways to Make People Save: a Social Marketing Approach, in Overcoming the Saving Slump: ow to Increase the Effectiveness of Financial Education and Saving Programs, edited by Annamaria Lusardi, Chicago: University of Chicago Press.

[20] Lusardi, Annamaria, and Olivia S. Mitchell (2014), The Economic Importance of Financial Literacy: Theory and Evidence, Journal of Economic Literature, 52(1).

[21] Lusardi, Annamaria, Pierre-Carl Michaud, and Olivia S. Mitchell (2016), Optimal Financial Knowledge and Wealth Inequality Forthcoming Journal of Political Economy. 
[22] Lusardi, Annamaria, nd Peter Tufano (2015), Debt Literacy, Financial Experiences, and Overindebtedness, Journal of Pension Economics and Finance, 14(4), pp. 332-368.

[23] Lusardi, Annamaria, and Peter Tufano (2015), Debt Literacy, Financial Experiences, and Overindebtedness, Journal of Pension Economics and Finance, 14(4), pp. 332-368.

[24] Mahdavi, Mahnaz and Nicholas Horton (2012), Financial Literacy Among Educated Women:Room for Improvement, Journal of Consumer Affairs, 48.

[25] Nandru, P., Anand, B., Rentala, S. (2016) Exploring the Factors Impacting Financial Inclusion: Evidence From South India, Annual Research Journal of SCMS, 4(1), 1-15.

[26] Soumare', I., Tchana, F.T., Kengne, T.M. (2016) Analysis of the Determinants of Financial Inclusion in Central and West Africa. Journal of Transnational Corporations Review, 8(4), 231 249. 